


\section{ENVIRONMENT AND DEVELOPMENT ECONOMICS}

published in association with the Beijer Institute of Ecological Economics, Royal Swedish Academy of Sciences

AIMS AND SCOPE Environment and Development Economics aims to publish papers on the environmental problems associated with the process of economic development. It encourages submission of two categories of paper. The first comprises scientific papers. The second comprises environmental policy discussion papers. The first is carried in a section on Theory and Applications. The second is carried in a regular section, Policy Options, and an occasional more focussed Policy Forum.

The journal publishes on a wide range of topics including:

* the environmental impact of economy-wide policies

* optimal environmental regulation and incentives in a development context

* the valuation of environmental resources in developing countries and incentives in environmental policy

* the environmental effects of institutional change

* modelling interdependent economic and environmental processes

SUBSCRIPTIONS Environment and Development Economics (ISSN 1355-770X) is published bimonthly in February, April, June, August, October and December. Six parts form a volume. The subscription price (excluding VAT), which includes print and electronic access, and postage, of Volume 18 in 2013 is $£ 297$ (\$481 in the USA, Canada and Mexico), for institutions and $£ 55$ ( $\$ 88$ in the USA, Canada and Mexico) for individuals ordering direct from the publisher and certifying that the journal is for their personal use. The electronic-only price available to institutional subscribers is $£ 236$ (US\$394 in the USA, Canada and Mexico). Single parts are $£ 54$ (US\$88 in the USA, Canada and Mexico). Prices include delivery by air where appropriate. Orders which must be accompanied by payment, may be sent to a bookseller, subscription agent or direct to the publisher: Cambridge University Press, The Edinburgh Building, Shaftesbury Road, Cambridge, CB2 8RU, UK: or in the USA, Canada and Mexico: Cambridge University Press, Journals Fulfillment Department, 100 Brook Hill Drive, West Nyack, New York 10994-2133. EU subscribers who are not registered for VAT should add VAT at their country's rate. VAT registered subscribers should provide their VAT registration number. Japanese prices for institutions are available from Kinokuniya Company Ltd, PO Box 55, Chitose, Tokyo 156, Japan. Special arrangements exist for subscribers in most low-income countries. Apply to: Journals Marketing Department, Cambridge University Press, University Printing House, Shaftesbury Road, Cambridge, CB2 8BS, UK.

Periodicals postage is paid at New York, NY, and at additional mailing offices. POSTMASTER: send address changes in the USA, Canada and Mexico to: Environment and Development Economics, Cambridge University Press, 100 Brook Hill Drive, West Nyack, New York 10994-2133.

Copying This journal is registered with the Copyright Clearance Center, 222 Rosewood Drive, Danvers, MA 01923, USA. Organizations in the USA who are also registered with C.C.C. may therefore copy material (beyond the limits permitted by sections 107 and 108 of U.S. Copyright law) subject to payment to C.C.C. of the per-copy fee of $\$ 12.00$. This consent does not extend to multiple copying for promotional or commercial purposes. Code 1355-770X/2013.

ISI Tear Sheet Service, 3501 Market Street, Philadelphia, PA 19104, USA, is authorised to supply single copies of separate articles for private use only.

Organizations authorised by the Copyright Licensing Agency may also copy material subject to the usual conditions.

For all other use, permission should be sought from Cambridge or from the American Branch of Cambridge University Press.

This journal is included in the Cambridge Journals Online service which can be found at http://journals.cambridge.org. For further information on other Press titles access http://www.cambridge.org 


\section{CONTENTS}

\section{THEORY AND APPLICATIONS}

LUCAS BRETSCHGER Climate policy and equity principles:

fair burden sharing in a dynamic world

JOHN HERBERT AINEMBABAZI, GERALD SHIVELY and ARILD ANGELSEN Charcoal production and household welfare in Uganda: a quantile regression approach

QUANG NGUYEN and PINGSUN LEUNG Revenue targeting in fisheries

ROBERT C. TATUM A hard row to hoe: farming on the economic frontier under incomplete property rights

HIDE-FUMI YOKOO and THOMAS C. KINNAMAN Global reuse and optimal waste policy

KINDIE GETNET and GEREMEW KEFYALEW Managing rainwater, improving livelihoods: assessing impacts using a Rainwater-Livelihoods-Poverty Index (RLPI)

ROBERT D. CAIRNS Sustainability or the measurement of wealth? 


\section{ENVIRONMENT AND DEVELOPMENT ECONOMICS}

published in association with the Beijer Institute, Royal Swedish Academy of Sciences

\section{EDITOR}

Anastasios Xepapadeas, Athens University of Economics and Business

\author{
ASSOCIATE EDITORS \\ Carlos Chávez, Universidad de Concepción \\ Margaret Chitiga, Human Sciences \\ Research Council, South Africa \\ Salvatore Di Falco, University of Geneva \\ Susana Ferreira, University of Georgia \\ George Halkos, University of Thessaly \\ Louis Hotte, University of Ottawa \\ Katrin Millock, CNRS, Paris School of \\ Economics \\ Subhrendu Pattanayak, Duke University
}

\author{
Karen Pittel, Ifo Institute for Economic \\ Research and University of Munich \\ Martin Quaas, Christian-Albrechts- \\ University of Kiel \\ Juan Robalino, CATIE and Universidad de \\ Costa Rica \\ Elizabeth Robinson, University of Reading \\ E. Somanathan, Indian Statistical Institute, \\ Delhi \\ Elisabetta Strazzera, University of Cagliari \\ Emi Uchida, University of Rhode Island \\ Mahmud Yesuf, American University
}

ASSISTANT EDITOR
Joan Stefan, Athens University of Economics and Business

\section{POLICY BOARD}

Kenneth Arrow, Stanford University, Edward B. Barbier, University of Wyoming, Partha Dasgupta, Cambridge University, Carl Folke, Beijer Institute, Gérard Gaudet, Université de Montréal, Rashid Hassan, University of Pretoria, Karl-Göran Mäler, Beijer Institute, Bernardo Mueller, University of Brasilia, Charles Perrings, Arizona State University, Rüdiger Pethig, University of Siegen, Mordechai Shechter, University of Haifa, Gerald Shively, Purdue University, V. Kerry Smith, Arizona State University, Jintao Xu, Peking University, Aart de Zeeuw, Tilburg University and Beijer Institute.

\section{EDITORIAL BOARD}

Francisco Alpízar, Tropical Agricultural and Higher Education Center, Costa Rica, Sangeeta Bansal, Jawaharlal Nehru University, New Delhi, Lucas Bretschger, Center of Economic Research at ETH Zurich, Robert Cairns, McGill University, Juan-Camilo Cárdenas, Universidad de los Andes, Bogotá, Maria Cunha e Sá, Universidade Nova de Lisboa, Hossein Farzin, University of California, Davis, Quentin Grafton, Australian National University, Michael Harris, University of Sydney, Jikun Huang, Chinese Academy of Sciences, Matti Liski, Helsinki School of Economics, Jane W. Kabubo-Mariara, University of Nairobi, JuanPablo Montero, Pontificia Universidad Católica de Chile, Keijiro Otsuka, National Graduate Institute for Policy Studies, Tokyo, Unai Pascual, University of Cambridge, Eustáquio Reis, Institute of Applied Economic Research (IPEA), Rio de Janeiro, Eftichis Sartzetakis, University of Macedonia, Bob Scholes, Council for Scientific and Industrial Research, Pretoria, Jim Shortle, Pennsylvania State University, Priya Shyamsundar, South Asian Network for Development and Environmental Economics, Bangkok, Jeff Vincent, Duke University, David Zilberman, University of California, Berkeley. 